\title{
家具の地震時滑り量の簡易評価 EVALUATION OF SLIDING DISPLACEMENT OF FURNITURE DURING EARTHQUAKE
}

\author{
金子美香 $-* 1 \quad$ 林 $\quad$ 康裕 $-* 1$
田村和夫 $-* 1$ \\ キーワート゚ \\ 家具, 滑り，摩擦係数，床応答，地盤種別，建物固有周期 \\ Keywords : \\ Furniture, Slide, Friction coefficient, Floor response, Soil condition, Natural \\ period
}

\author{
Mika KANEKO —* 1 \\ Kazuo TAMURA $-* 1$ \\ Yasuhiro HAYASH $-* 1$
}

A new formula to estimate sliding displacements of furniture during earthquakes is proposed. This formula indicates that sliding displacements are proportional to the square of input velocity and inversely proportional to friction coefficients. It is ascertained by analyses using a simple model and various input waves that the formula indicates almost maximum sliding displacement of furniture for an input velocity. By using this formula, we evaluated sliding displacements of furniture under various conditions. As the results, it becomes clear that sliding displacements are largely influenced by friction coefficients, soil conditions and floors where furniture is installed.

\section{1.はじめに}

1995年兵庫県南部地震をはじめとする大地震の被害報告では、室内 の家具等の転倒・散乱による人的被害が数多く報告されている刚えは1。 このように室内の安全性の観点からも、家具類の地震時挙動を把握し ておくことは重要と考えられる。家具（矩形の二次元剛体に置換され ることが多い)の地震時の転倒限界については、現在までにさまざま な研究が行われ明六 (1233)、転倒限界式が提案されている。但し、これら は家具が滑らない、或いは滑りにくいという条件下で検討されたもの が多い。一方、実際の地震では、家具が滑って大きく移動した事例 1 も多く見られる。家具の移動量が大きい場合には、他の家具と衝突し たり、移動中に脚部が何かにひっかかり転倒することも考えられ、危 険な状態に成り得る。このことから、家具の滑り量に関する検討も重 要と考えられる。

本報では、家具の設置床が水平方向に振動した場合に転倒または ロッキング振動よりも滑りが生じやすい(1)式の条件下で、地震時の家 具の滑り量について検討する。

$$
\mu<b / h
$$

ここで、 $\mu$ は家具と床との静摩擦係数、 $b / h$ は家具の幅高さ比である。 筆者らは、過去に(1)式を満たす条件下で、剛体モデルにさまざまな観 測地震波を入力して解析を行い、剛体の滑り量と入力速度の間に強い 相関があること、滑り量は剛体の形状に影響されないことを示した3)。

本報では、まず、家具を一自由度系でモデル化し、模擬地震波、観 測地震波、床応答波を入力した解析により、家具の最大滑り量を求め る。次に、その結果を基に滑り量の算定式を提案する。また、提案し た算定式を用いて建物内の家具の地震時滑り量を簡易的に評価し、家 具の滑り量に影響を及ほす要因について考察する。

\section{2. 家具の滑り解析と最大滑り量の算定式}

\section{1 解析モデルと摩擦係数}

解析モデルは図 1 に示す一自由度系とした。水平方向ばねの履歴特 性は、静摩擦係数と動摩擦係数が等しいと仮定して、完全弾塑性型の バイリニアーモデルとした。線形時のばね剛性は剛と仮定し、解析上 は固有振動数が $50 \mathrm{~Hz}$ となるような值を与えた。なお、固有振動数の 値を数 $\mathrm{Hz}$ 程度にしても、最大滑り量があまり変わらないことを、別 途確認している。入力は水平一方向とし、解析方法にはNewmarkの $\beta$ 法を用いた。

摩擦係数 $\mu$ は、家具が滑るかどうかの判定、あるいは滑り量に影響 する重要なパラメータである。筆者らが家具と床面との静摩擦係数お よび動摩擦係数の計測を行った結果を、参考值として図 2 に示す。こ れらは、床に置かれた家具を水平にばねばかりで引っ張り、静摩擦力 と動摩擦力を計測し、家具の重量で割った值である。計測には、テー ブル、椅子、本棚、ドレッサーなど 9 種類の家具を用いた。これらは 全て木製（床との設置面も木製）で、重量は30kg 以下である。林面 の材質としては、木質材、絨㓙、畳、塩ビシートの 4 種類を用いた。 同じ床面でも、家具による摩擦係数のばらつきは大きい。䋐轮で静摩 擦係数 0.93 と 0.53 のケースは、家具が長期間同じ場所に設置されてい たケースであり、絨毯の沈み込みが大きかったものと考えられる。 従って、同様の影響があると考えられる畳や塩ビシートでも、重量が 重く長期間設置された家具では、より大きな摩擦係数になる可能性が ある。解析では、キャスターなどの滑りやすい条件も含めて、摩擦係 数 $\mu$ を $0.1 、 0.3 、 0.5$ の 3 種類とした。

\section{2 入力波}

2.1 に示した解析モデルへの入力波としては、模擬地震波、観測地

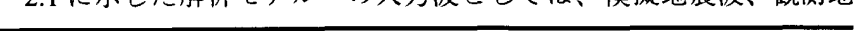

*1 Izumi Research Institute, Shimizu Corporation, Dr. Eng.

\footnotetext{
*1 清水建設陎和泉研究室 工博

（下100-0011 千代田区内幸町2-2-2)
} 
震波、床応答波を用いた。以下に、各波の作成方法を示す。

\section{模擬地霞波}

模擬地震波は、建築物荷重指針4)(以下、荷重指針と呼ぶ) に示され ている地震動の加速度応答スペクトル $S_{A}$ にフィッティングするよう に作成した。荷重指針では、 $S_{A}$ を(2)、(3)式のように設定している。

$$
S_{A}\left(T_{s}, h_{s}\right)= \begin{cases}\left(1+\frac{f_{A}-1}{d} \frac{T_{s}}{T_{c}}\right) G_{A} R_{A} A_{0} \cdot F_{h s} & , 0 \leq T_{s} \leq d T_{c} \\ f_{A} G_{A} R_{A} A_{0} \cdot F_{h s} & , d T_{c} \leq T_{s} \leq T_{c} \\ \frac{2 \pi f_{V} G_{V} R_{V} V_{0}}{T_{s}} \cdot F_{h s} & , T_{c} \leq T_{s}\end{cases}
$$

$$
T_{c}=\frac{2 \pi f_{V} G_{V} R_{V} V_{0}}{f_{A} G_{A} R_{A} A_{0}}
$$

ここで、 $F_{h s}$ は $h_{s}=0.05$ 以外の隇衰に対する補正係数、 $A_{0} 、 V_{0}$ は標準地 盤の地震動の基本最大加速度および最大速度、 $R_{A} 、 R_{V}$ は加速度および 速度の再現期間換算係数、 $G_{A} 、 G_{V}$ は地盤種別補正係数である。今、地 震動の最大加速度 $A_{g}$ と速度 $V_{g}$ が与えられている時、 $A_{g}=G_{A} R_{A} A_{0}$ 、 $V_{g}=G_{V} R_{V} V_{0}$ として(2)、(3)式を春き換えると、(4)、(5)式となる。ここ では $f_{A}=2.5 、 f_{V}=2.0 、 d=0.5$ という荷重指針の推奖値を用いた。

$$
\begin{aligned}
& S_{A}\left(T_{s}, h_{s}\right)= \begin{cases}\left(1+3 T_{s} / T_{c}\right) A_{g} \cdot F_{h s} & , 0 \leq T_{s} \leq T_{c} / 2 \\
2.5 A_{g} \cdot F_{h s} & , T_{c} / 2 \leq T_{s} \leq T_{c} \\
4 \pi V_{g} / T_{s} \cdot F_{h s} & , T_{c} \leq T_{s}\end{cases} \\
& T_{c}=1.6 \pi V_{g} / A_{g}
\end{aligned}
$$

荷重指針では、第 I 種、第 II 種、第 III 種の各地盤種別に対して、 $G_{A}$ $=1.0,1.2,1.2 、 G_{V}=1.0,2.0,3.0$ の值が推奖されている。また、第 $\mathrm{I}$ 種地盤 のでは、 $A_{0}=15 V_{0}$ の関係式が示されている。これらの関係より、ここ では、 $V_{g}=10 \mathrm{~cm} / \mathrm{s}$ とした場合の各地盤種別での $A_{g}$ を $150 \mathrm{Gal} 、 90 \mathrm{Gal} 、$ $60 \mathrm{Gal}$ とした。 $T_{c}$ は荷重指針より、0.33秒、0.56秒、0.84秒と与えた。 $V_{g}=10 \mathrm{~cm} / \mathrm{s}$ とした場合の各地盤種別の $S_{A}\left(h_{s}=0.05\right)$ の值を図 3 に示 す。本検討では、図3の $S_{A}\left(h_{s}=0.05\right)$ にフィッティングするように波 を作成した。

模擬地震波の時刻歴包絡形は Jennings 型5)とし、各地盤種別におい て継続時間（振幅が最大值の $1 / 10$ となるまでの時間） 5 秒、 20 秒、40 秒の 3 種類の波を作成した。位相はランダムとし、無作為に初期値を 与えて各地盤種別、各継続時間について10波ずつ作成した。図 4 に作 成した模擬地震波の波形例を示す。

\section{観測地震波}

観測地震波としては、表 1 に示す日本および米国の強震記録24波を 用いた。これらの波を $V_{g}=10 \mathrm{~cm} / \mathrm{s}$ となるように基準化した時の速度応 答スペクトル $(h=0.05)$ を、図5(a)に点線で重ね描いた。比較のため、荷 重指針の第II種地盤の加速度応答スペクトルを、 $T_{s} / 2 \pi$ を乗じること で速度応答スペクトルに換算した值も実線で示した。図より、用いた 観測記録は、短周期側（約 1.0 秒以下）で波によるばらつきが大きい が、荷重指針のスペクトルはその中間的な值であることがわかる。ま た、長周期側（約 2.0 秒以上）では、観測地震波のスペクトルの方が 荷重指針よりも小さくなっている。

\section{床応答波}

床応答波としては、表 1 の観測地震波を線形一自由度系に入力した 時の応答波を用いた。一自由度系の固有周期は 0.5 秒、 1.0 秒、 2.0 秒 の 3 種類、隇衰定数はいずれも $h=0.03$ とした。床応答波の速度応答ス ペクトル $(h=0.05)$ を最大速度 $10 \mathrm{~cm} / \mathrm{s}$ に基準化して図 5(b)〜(d)に示す。
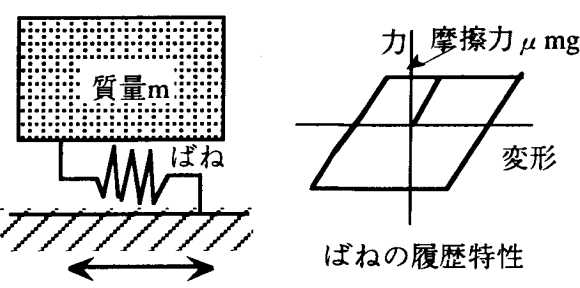

ばねの履歴特性

図 1 解析モデル

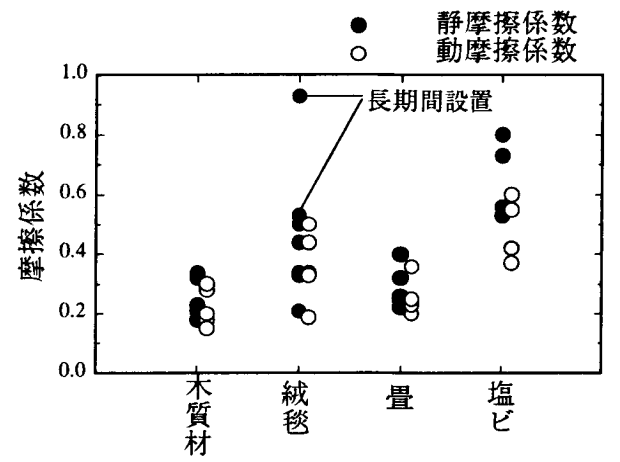

図 2 実測による木製家具(重量 $30 \mathrm{~kg}$ 以下)と床との摩擦係数

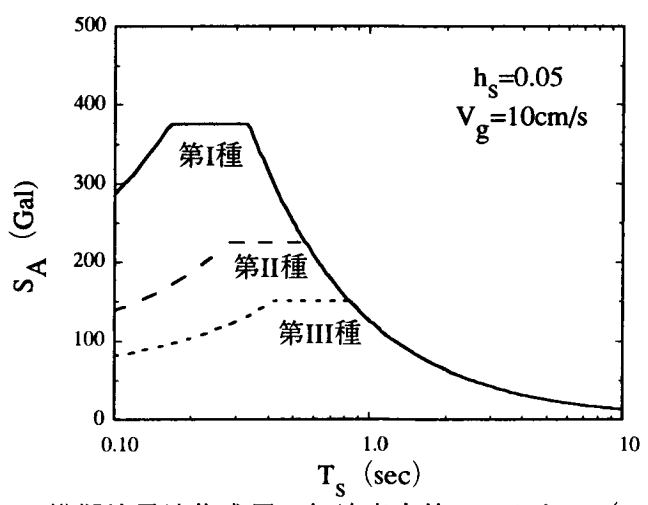

図 3 模擬地震波作成用の加速度応答スペクトル（(4)式）

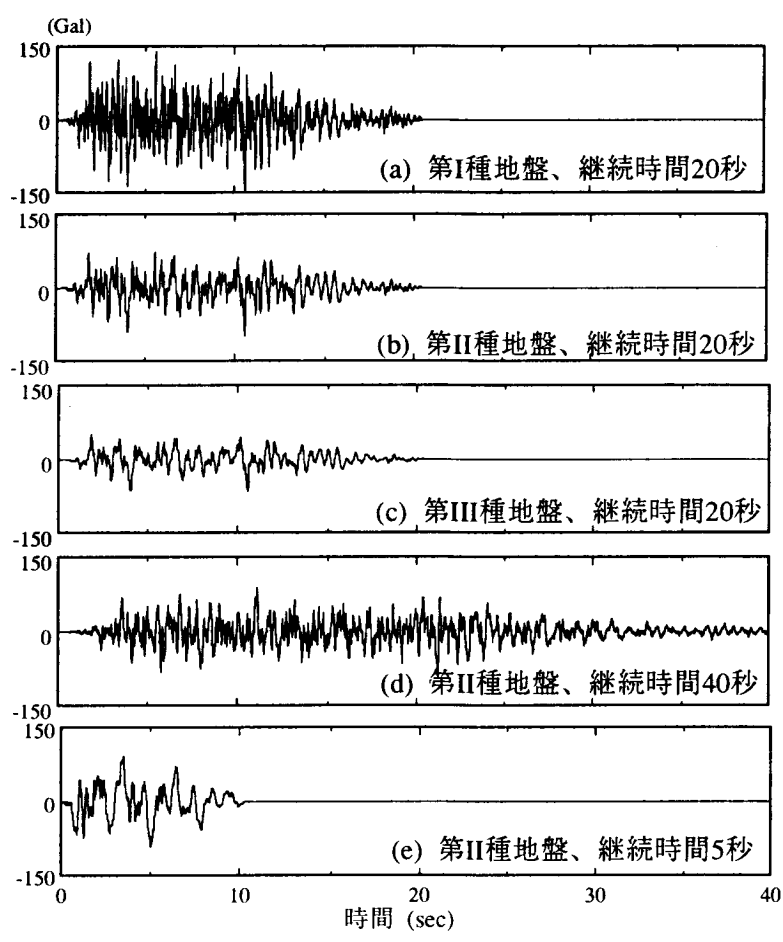

図 4 模擬地震波の波形例 
表 1 解析に用いた観測地震波

\begin{tabular}{|c|c|c|c|c|c|c|c|c|c|}
\hline No. & 発生日 & 地震名 & 観測場所 & 成 & No. & 発生日 & 地震名 & 観測場所 & 成分 \\
\hline 1 & 1966.05 .28 & 松代 & 松代 & SN & 13 & 1994.10 .04 & 北海道東方沖 & 根室 & EW \\
\hline 2 & 1966.05 .28 & 松代 & 落合 & S35E & 14 & 1994.12.28 & 三陸はるか沖 & 八戸 & NS \\
\hline 3 & 1968.05 .16 & 十勝沖 & 八戸 & SN & 15 & 1994.12.28 & 三陸はるか沖 & 青森 & EW \\
\hline 4 & 1978.06 .12 & 宮城県沖 & 東北大 & NS & 16 & 1995.01.17 & 兵庫県南部 & JMA 神戸 & NS \\
\hline 5 & 1987.12.17 & 千葉県東方沖 & 勝浦 & NS & 17 & 1995.01 .17 & 兵庫県南部 & 莫合 & $\mathrm{N} 37 \mathrm{~W}$ \\
\hline 6 & 1987.12.17 & 千葉県東方沖 & 木更津 & NS & 18 & 1940.05 .18 & Imperial Valley & El Centro & NS \\
\hline 7 & 1987.12.17 & 千葉県東方沖 & 木更津 & EW & 19 & 1949.04 .13 & Olympia & Olympia & EW \\
\hline 8 & 1989.07.09 & 伊豆半島東方沖 & 伊東 & $10 \mathrm{E}$ & 20 & 1952.07.21 & Kern County & Taft & EW \\
\hline 9 & 1993.01.15 & 釧路沖 & 釧路 & EW & 21 & 1971.02.09 & San Fernando & Pacoima Dam & S16w \\
\hline 10 & 1993.01.15 & 釧路沖 & 根室 & EW & 22 & 1994.01 .17 & Northridge & Newhall & $360 \mathrm{D}$ \\
\hline 11 & 1993.07.12 & 北海道南西沖 & 寿都 & NS & 23 & 1994.01 .17 & Northridge & Sylmar & 360D \\
\hline 12 & 1994.10 .04 & 北海道東方沖 & 根室 & EW & 24 & 1994.01.17 & Northridge & Tarzana & 90D \\
\hline
\end{tabular}

波によるばらつきは観測地震波より小さく、ど
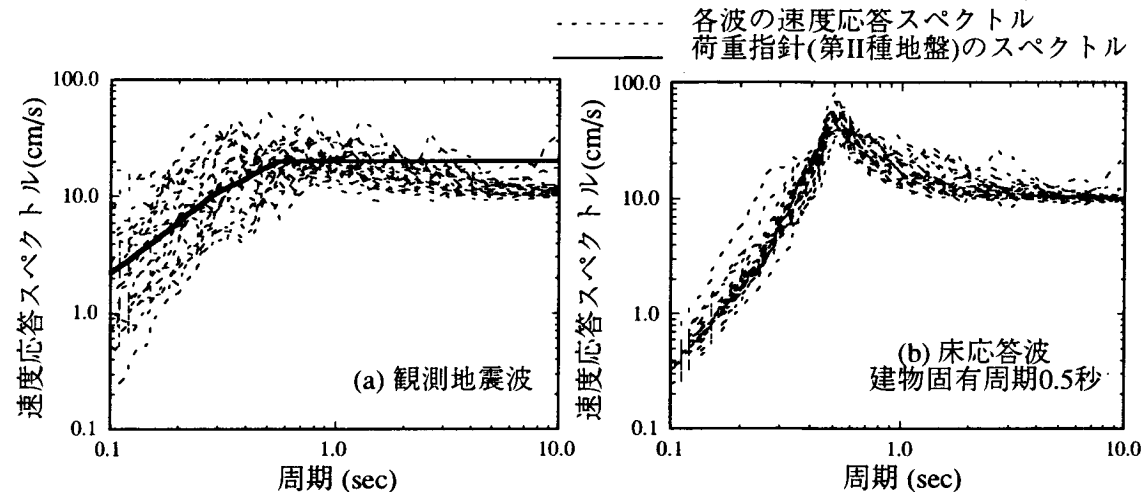

の波も固有周期付近の成分が卓越している。

\section{3 剛体の最大滑り量}

2.1 に示した解析モデルに2.2で作成した波を 入力し、剛体の最大滑り量を求めた。模擬地震 波の場合には(4)式の $V_{g}$ が、観測地震波と床応 答波の場合には各波の最大速度が $10 \mathrm{~cm} / \mathrm{s}$ から $150 \mathrm{~cm} / \mathrm{s}$ まで $10 \mathrm{~cm} / \mathrm{s}$ 刻みとなるように基準化し て用いた。結果の例を図6に示す。・は解析によ る最大滑り量の值である。実線は滑り量の算定 式であるが、これについては2.4で説明する。(a) 〜(c)は模擬地震波入力の場合である。(a)は地盤 種別による違い、(b)は入力地震波の継続時間に よる違い、(c)は摩擦係数による違いを比較した ものである。これらの図より、地盤種別や波の 継続時間による滑り量の違いはほとんど見られ ず、滑り量には摩擦係数が大きく影響している ことがわかる。

(d)は観測地震波を入力した場合の摩擦係数に よる違いを比較をしたものである。摩擦係数
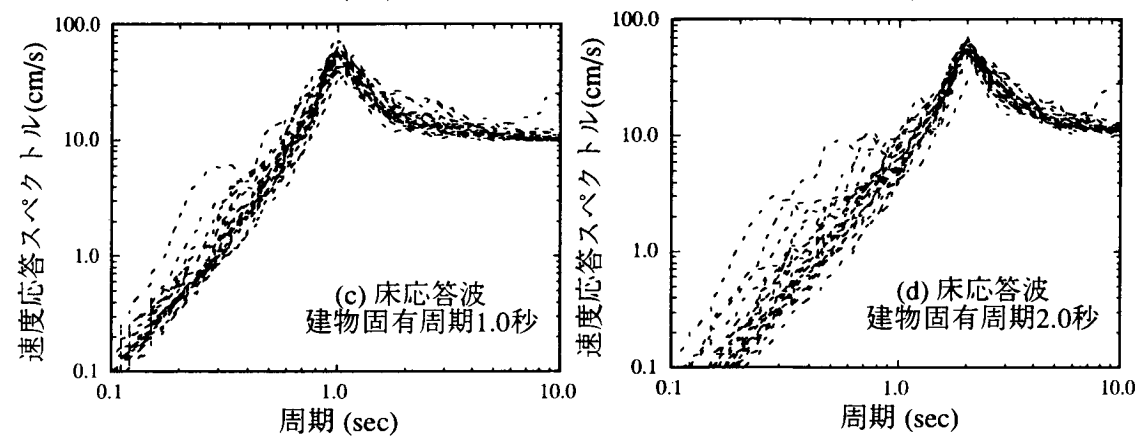

図 5 観測地震波および床応答波の速度応答スペクトル

（最大速度 $10 \mathrm{~cm} / \mathrm{s}$ に基準化、 $\mathrm{h}=0.05$ ）

0.1 の場合には、約 $50 \mathrm{~cm} / \mathrm{s}$ 以上の入力で、(c)の模擬地震波入力の場合上 ク滑り量が小さくなっている。これは、図5(a)に示したように、用い た観測地震波の長周期成分が模擬地震波よりも少ないためと考えられ る。摩擦係数 0.3 と 0.5 の場合には、模擬地震波の滑り量よりもばらつ きが大きくなっている。これは、模擬地震波の場合にはどの波もほほ 一定の速度で滑り始めるのに対し、観測地震波の場合には、波により 滑り出す速度に違いがあるためと考えられる。

(e)は、床応答波入力の場合に、建物の固有周期による違いを比較し たものである。固有周期の長い建物の方が、入力レベルの大きいとこ ろで滑り量がやや大きくなっている。

\section{4 滑り量の算定式}

バイリニアー形の復元力特性をもつ弾塑性系の地震応答では、系が 比較的短周期の場合には、一般にエネルギー一定則が成り立つことが 知られている6。最大滑り量においても同様の関係が成り立つとする と、図 7 に示すパラメータを用いて(6)式が成り立つ。

$$
\frac{1}{2} k \delta_{L}^{2}=\mu m g\left(\delta_{S}-\delta_{y} / 2\right)
$$

ここで、 $\delta_{y} \ll<\delta_{S}$ とすると、 $\delta_{S}$ は(7)式で表される。

$$
\delta_{S}=\frac{k}{2 m g} \frac{\delta_{L}^{2}}{\mu}
$$

(7)式から、最大滑り量は入カレベルの 2 乗に比例し、摩擦係数に反比 例するという関係が得られる。最大滑り量と入力速度との相関が高い ことは既に確認されているため)、ここでは、入力速度の 2 乗に比例 し、摩擦係数に反比例するという関係で表すものとした。また算定式 は、最大滑り量のほほ上限を抑えるように設定するものとした。以上 の考え方で設定された最大滑り量の算定式が(8)式である。

$$
\delta_{S}=\left\{\begin{array}{cl}
\frac{0.0015}{\mu} V^{2} & , V \geq \frac{\mu g}{2 \pi F_{e}} \\
0 & , V<\frac{\mu g}{2 \pi F_{e}}
\end{array}\right.
$$

(8)式では、家具に加わる水平力が摩擦力を超えるかどうかで、滑りの 有無を判断している。ここで、 $\delta_{S}$ は最大滑り量 $[\mathrm{cm}] 、 \mu$ は摩擦係数、 $V$ は入力最大速度 $[\mathrm{cm} / \mathrm{s}] 、 g$ は重力加速度 $[\mathrm{Gal}] 、 F_{e}$ は入力波の最大加速度 $A$ と最大速度 $V$ の比から(9)式で求められる振動数 $[\mathrm{Hz}]$ (等価振動数と 呼ぶ)である。 

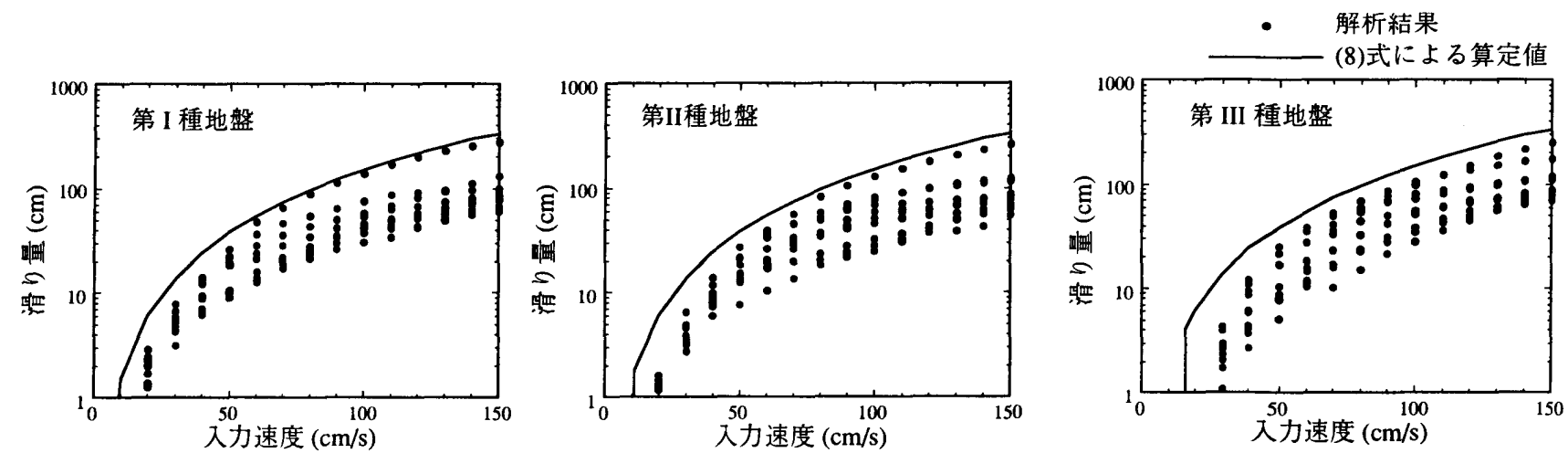

(a) 地盤種別による滑り量の違い（模擬地震波入力, 摩擦係数 0.1 , 継続時間 20秒)
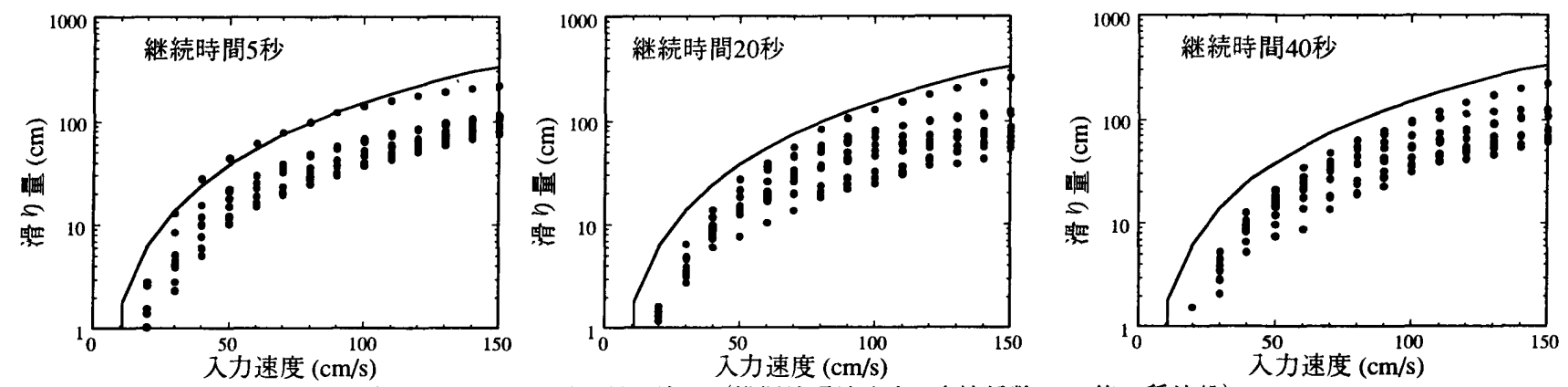

(b) 継続時間による滑り量の違い（模擬地震波入力，摩擦係数 0.1 , 第 II 種地盤）
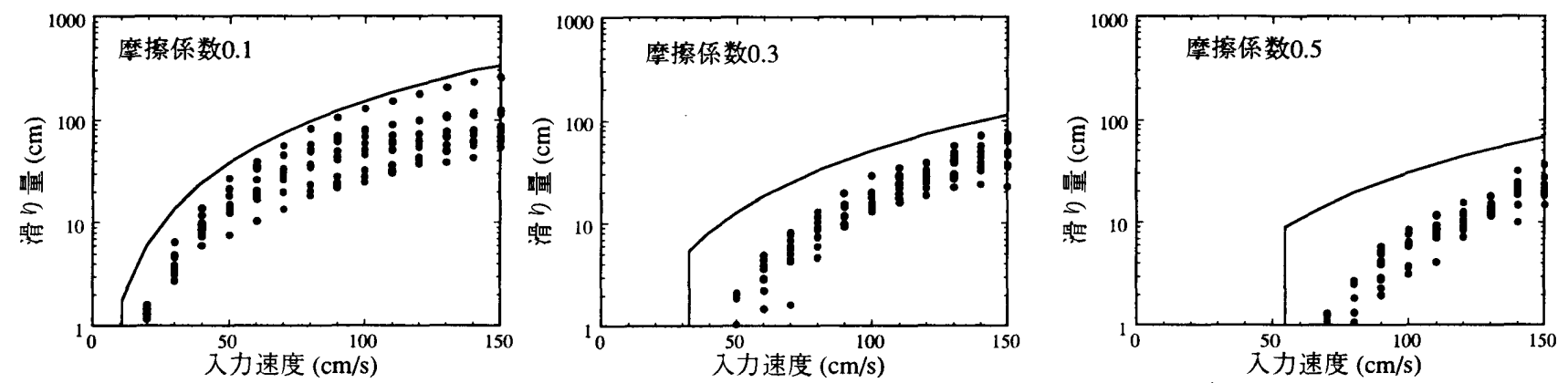

(c) 摩擦係数による滑り量の違い（模擬地震波入力，第 II 種地盤，継続時間 20秒）
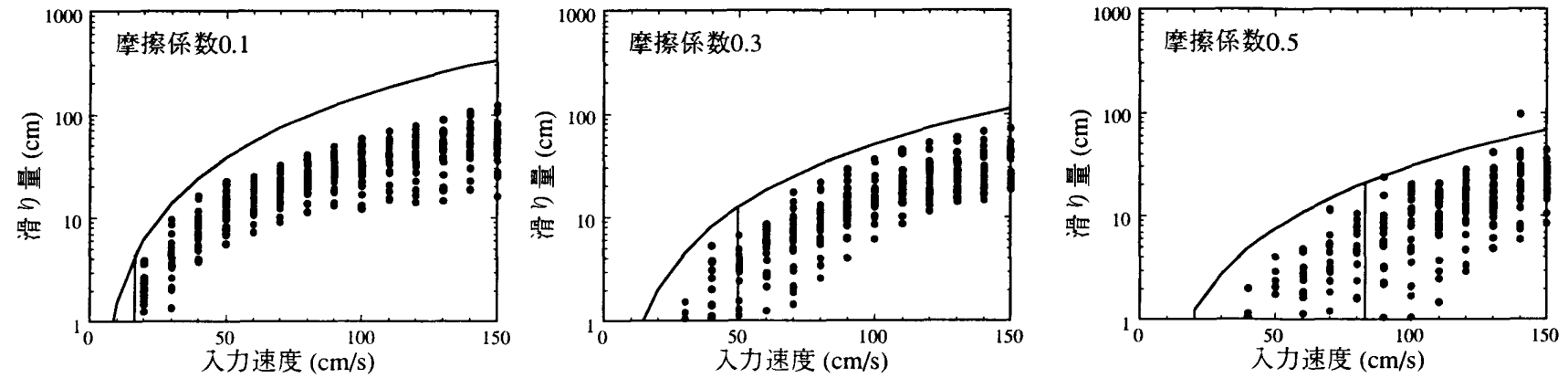

(d) 摩擦係数による滑り量の違い（観測地震波入力）
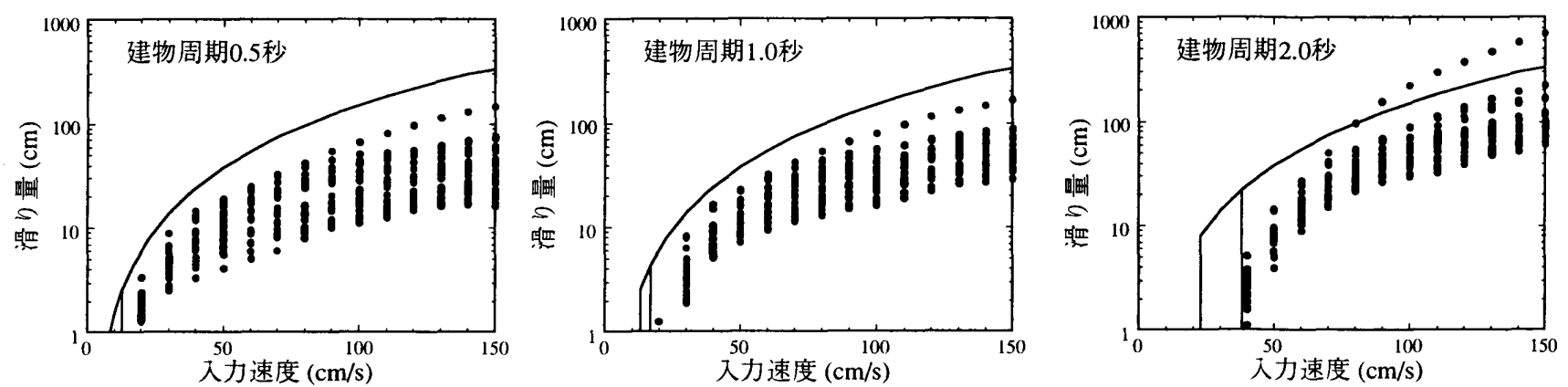

(e) 建物卓越周期による滑り量の違い（床応答波入力，摩擦係数 0.1)

図 6 解析による家具の最大滑り量と滑り量の算定式の值 


$$
F_{e}=A / 2 \pi V
$$

(8)式による算定值を図6に実線で示した。観測地震波入力と床応答 波入力の場合には、等価振動数の值が波により異なるため、最大と最 小の等価振動数を用いて求めた 2 種類の線を示した。摩擦係数 0.1 の 場合には、観測地震波や建物周期 0.5 秒の床応答波の速度の大きい入 力で、算定式が過大評価になっている。これは、入力波に長周期成分 が少ないためと考えられよう。逆に、摩擦係数 $0.3 、 0.5$ の場合には、 滑り始める入力速度付近で算定式が過大評価になっている。こよう に、一部の入力条件に対しては過大評価になるものの、本算定式は、 ほほ解析結果の上限を与える式になっている。このため、簡易的に家 具の地震時滑り量を算定する際には、本式が役立つものと考える。

\section{3. 家具の地震時滑り量の简易評価}

\section{1 简易評価方法}

2.4 の滑り量の算定式を用いて、建物内に設置された家具の地震時 滑り量を簡易的に評価する。家具の滑り量の評価位置は、建物 1 階と 1 次モードの等価高さ（以下、等価高さと呼ぶ）とする。等価高さは、

一般に建物高さの 0.7 倍程度である。

建物 1 階に設置された家具の滑り量は、1 階の床応答が地表面地震 動と同一であると仮定すれば、地表面地震動の最大加速度 $A_{g}$ と最大 速度 $V_{g}$ から、(8)式、(9)式を用いて算定することができる。一方、建物 等価高さに設置された家具の滑り量を算定するには、等価高さでの床 応答加速度 $A_{f}$ および速度 $V_{f}$ を求める必要がある。 $A_{f}$ および $V_{f}$ は、 以下のように算定するものとした。

(1) 建物を 1 自由度系とし、地表面地震動の最大加速度 $A_{g}$ と最大速度 $V_{g}$ から、(4)式の関係を用いて、等価高さでの最大加速度 $A_{f}$ を求める。 (2) 等価高さでの最大速度 $V_{f}$ は、(10)式、(11)式から求める。

$$
\begin{aligned}
V_{f} & = \begin{cases}A_{f} / 2 \pi F_{s} & , F_{s} \leq F_{e, g} \\
\sqrt{V_{g}^{2}+\left(A_{r} / 2 \pi F_{s}\right)^{2}} & , F_{s}>F_{e, g}\end{cases} \\
A_{r} & =\sqrt{A_{f}^{2}-A_{g}{ }^{2}}
\end{aligned}
$$

$F_{s}$ は建物の固有振動数、 $F_{e, g}$ は地表面地震動の等価振動数である。建 物の線形（または等価線形）モデルが設定できれば、(1)(2)により建物 応答を簡易評価できることは、文献 7)で確認されている。 $A_{g}$ およ゙ $V_{g}$ は、(12)式8)と(13)式9の距離隇衰式から求めるものとする。

$$
\begin{aligned}
\log A_{g}= & 0.42 M_{w}-\log \left(R+0.025 \cdot 10^{0.42 M_{w}}\right)-0.0033 R+1.22 \\
\log V_{g}= & -0.22 M_{w}^{2}+3.94 M_{w}-\log \left(R+0.01 \cdot 10^{0.43 M_{w}}\right) \\
& -0.002 R-11.9-0.71 \cdot \log V_{s} \quad, V_{s}=400(\mathrm{~m} / \mathrm{s})
\end{aligned}
$$

ここで、 $M_{w}$ は地震のモーメントマグニチュード、Rは断層距離 $[\mathrm{km}]$ で ある。 $M_{w}$ の気象庁マグニチュード $M_{J}$ への換算は、 $M_{w}$ の定義式(10)と 地震モーメント $M_{0}$ と $M_{J}$ の関係の半経験式 ${ }^{11)}$ をいることにより可 能である。(13)式のマグニチュードの適用範囲から、6.8 $\leq M_{J} \leq 7.6$ （6.5 $\leq M_{W} \leq 7.8 ）$ とした。得られた $A_{g}$ および $V_{g}$ の值は第 II 種地盤 上での值と仮定し、第 I 種地盤では $A_{g}$ を $1 / 1.2$ 倍、 $V_{g}$ を 0.5 倍、第 III 種地盤では $A_{g}$ を 1 倍、 $V_{g}$ を 1.5 倍した。

本検討で用いた家具の滑り量の簡易評価フローを図8に示す。建物 としては、固有周期 0.5 秒、 1.0 秒、2.0秒のものを考え、減衰定数は いずれも $h_{s}=0.03$ とした。減衰の補正係数 $F_{h s}$ には、(14)式4)を用いた。

$$
F_{h s}=1.5 /\left(1+10 h_{s}\right)
$$

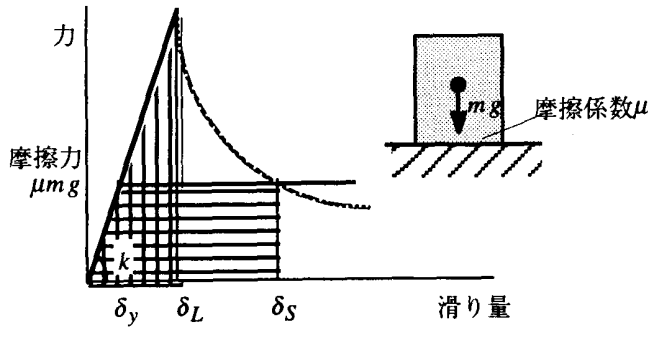

図 7 エネルギー一定則と最大滑り量 $\delta_{S}$

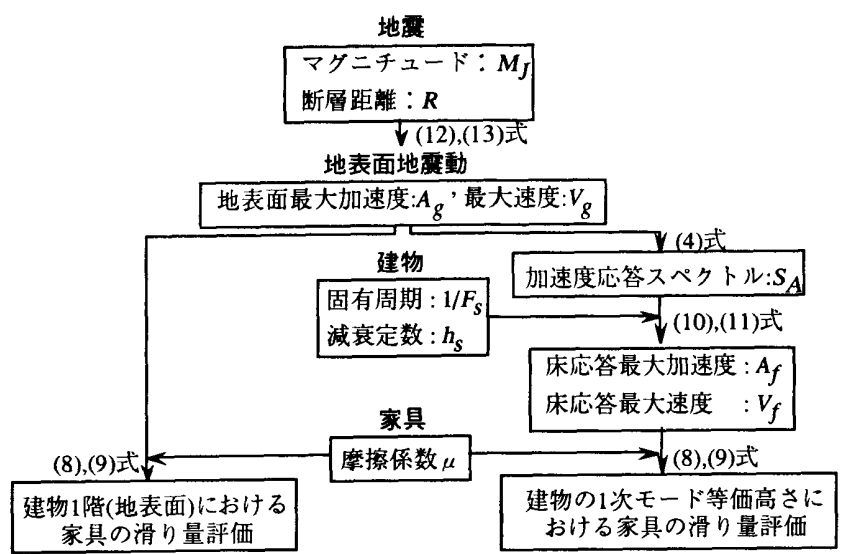

図 8 本検討で用いた家具の滑り量の簢易評価フロー

\section{2 简易評価結果}

3.1 の方法で評価した家具の滑り量を図9 図12に示す。いずれも、 横軸にマグニチュード $M_{J}$ 、維軸に断層距離 $R$ をとり、滑り量をコン 夕ーで表している。図 9 は建物 1 階での評価結果（摩擦係数 0.1）、図 10 は等価高さでの評価結果（第 II 種地篮、摩擦係数 0.1)、図 11 は建 物 1 階での評価結果（第 II 種地盤、摩擦係数 0.3 ）、図 12 は等価高さ での評価結果（第 II 種地盤、摩擦係数 0.3）である。

図 9 の(a)(b)(c)を比較すると、地盤種別により、家具の滑り量に大 きな違いがあることがわかる。これは、地表面地震動の最大速度を、 第 I 種地盤：第 II 種地盤：第 III 種地盤 $=1: 2: 3$ と設定しており、家 具の滑り量には、その 2 乗の值が影響しているためである。

図9(b)と図 10 を比較すると、周期 1.0 秒、2.0秒の建物の $M_{J}$ が小さ くRの大きい領域で滑らないと判定されている以外は、等価高さでの 滑り量は、1階での滑り量よりかなり大きくなっている。また、摩擦 係数 0.3 の場合 (図 11 と図 12 の比較)にも同様の傾向が見られる。図 10 において建物による違いを見ると、周期の長い建物ほど滑り出す $M_{J}$ とRの領域は限定されるが、一旦滑り出すと滑り量は大きくなっ ている。また、滑っている領域での(b)と(c)の滑り量は同じ值である。 これは、どちらの建物の固有周期も地盤の卓越周期に比べて長く、地 震動の速度応答スペクトルが一定となる周期領域に入っているためで ある。

摩擦係数による違いを建物 1 階で比較（図9(b) と図 11）すると、摩 擦係数 0.3 の場合に家具が滑る領域は、摩擦係数 0.1 の場合に比べて 断層距離がかなり短い範囲に限定されていることがわかる。建物等価 高さで比較（図 10 と図 12）しても、摩擦係数 0.3 の方が家具の滑り 出す $M_{J}$ とRの領域は限定され、滑り量も小さくなっている。

4. まとめ

摩擦係数が家具の幅高さ比よりも小さい条件 ((1)式)下で、家具の 


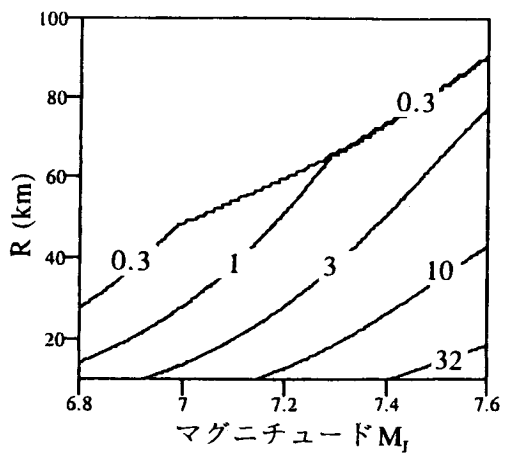

(a) 第 I 種地盤

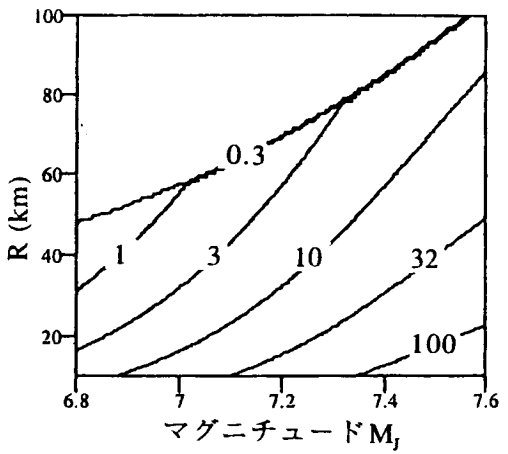

(b) 第 II 種地盤

図 9 建物 1 階での滑り量評価結果： $\delta_{s}$ （摩擦係数 0.1）

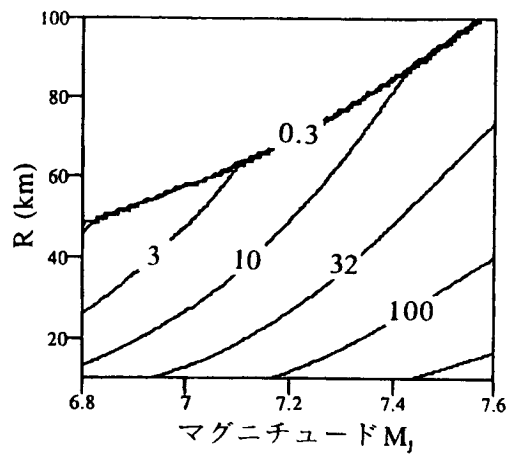

(c) 第 III 種地盤

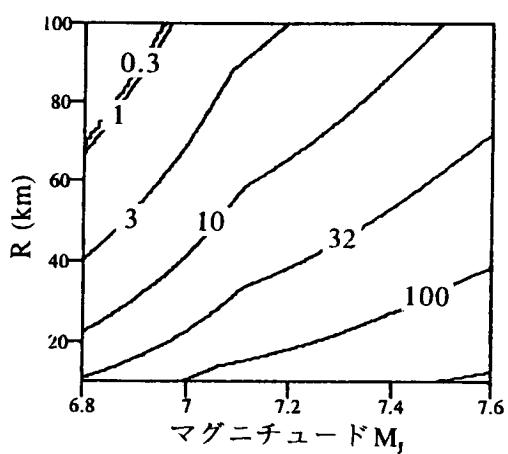

(a) 建物周期 0.5 秒

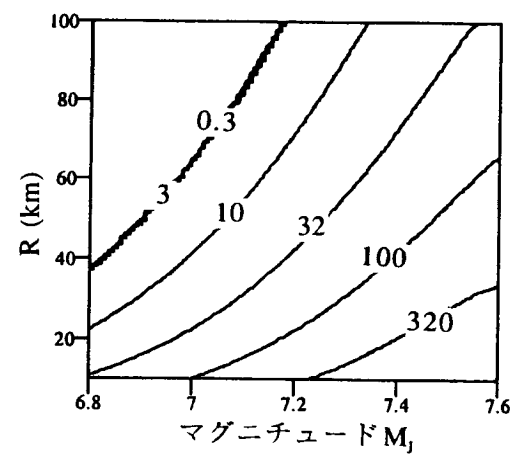

(b) 建物周期 1.0 秒

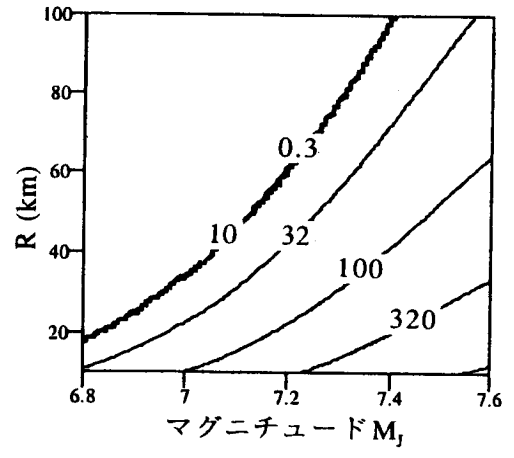

(c) 建物周期 2.0 秒

図 10 建物等価高さでの滑り量評価結果 : $\delta_{s}$ （第 II 種地盤、摩擦係数 0.1）

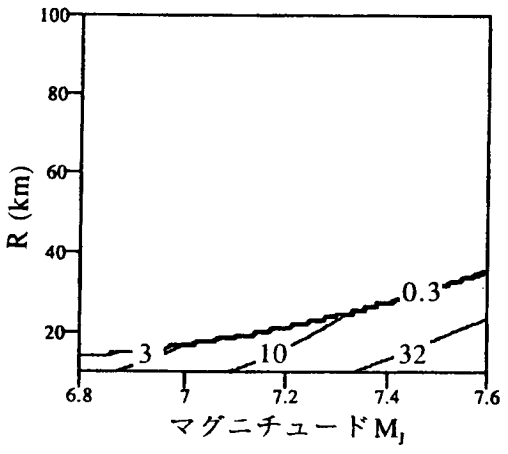

図 11 建物 1 階での滑り量評価結果 : $\delta_{s}$ (第 II 種地盤、摩擦係数 0.3 )

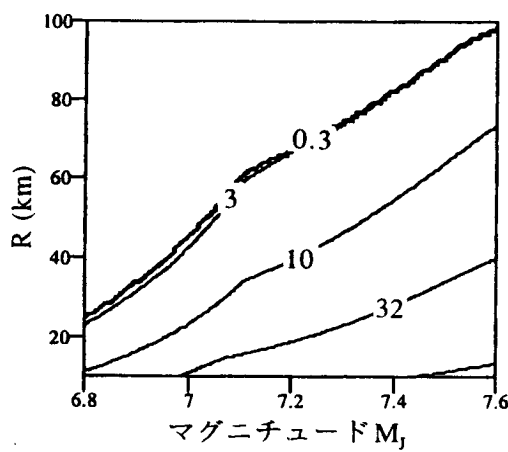

(a) 建物周期 0.5 秒

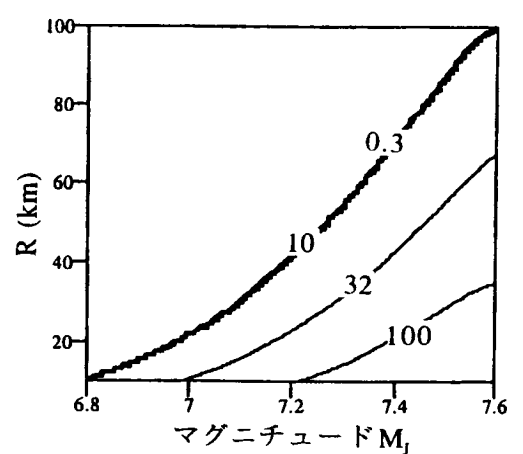

(b)建物周期 1.0 秒

図 12 建物等価高さでの滑り量評価結果 : $\delta_{s}$ （第 II 種地盤、摩擦係数 0.3）

最大滑り量の算定式を提案した。この算定式は、種々の入力波を用い た解析結果から、一部の入力条件で過大評価になることを除けば、ほ ほ最大滑り量の上限值を与える式であると言える。また、この算定式 を用いて家具の滑り量の簡易評価を行い、家具の滑り量には、摩擦係 数、地盤種別、設置階が大きく影響することを示した。今後は、地震 時の家具の転倒評価と滑り量評価とを組み合わせて、家具の地震時安 定性の評価に役立てていきたい。

\section{謝辞}

表 1 の地震波は、以下の機関により観測又は提供されたものです。関係された 方々に謝意を表します。/日本建筑センター、東北大学、防災科学技術研究所、 東大地震研究所、日本気象協会、関西地震観測研究協議会、C.D.M.G、大阪瓦斯/

\section{参考文献}

1) 日本建箖学会建筑計画委員会: 建築内部空間における被害WG:阪神淡路大震 災 住宅内部被害調查報告書、1996 年
2) Ishiyama, Y. : Criteria for Overturning of Bodies by Earthquake Excitations, Transactions of A.I.J, No.317, July 1982.

3) 金子美香、林康裕 : 地震時の剛体の転倒限界と移動量に関する検討、構造工 学論文集、Vol.43B、1997年 3 月.

4) 日本建築学会 : 建築物荷重指針·同解説、1993 年 6 月

5) Jennings,P.C., G.W.Housner and N.C.Tsai : Simulated earthquake motions, Earthq. Eng. Res. Lab., California Institute of Technology, 1968.

6) 柴田明德 : 最新耐震構造解析、森北出版、1981 年 6 月.

7) 金子美香、林康裕、田村和夫、神原浩 : 地震時の家具の転倒可能性評価（そ の1）（その 2 ）、日本建築学会大会学術講演梗概集、1998 年 9 月.

8) Fukushima,Y. and T.Tanaka : A new attenuation relation for peak horizontal acceleration of strong earthquake ground motion in Japan, BSSA 80, pp.757-783, 1990.

9) Midorikawa,S. : Preliminary analysis for attenuation of peak ground velocity on stiff site, Proc. of the Intern. Workshop on Strong Motion Data, 2, pp.39-48, 1993.

10) Kanamori,H. : The energy release in great earthquakes, J. Geophys. Res. 82, pp.2981$2987,1977$.

11) 福島美光,田中貞二: 気象庁マグニチュードによる震源スペクトルのスケー リング則，日本建築学会論文乹告集, 425,pp.19-25, 1991 .

[1998年10月20日原稿受理 1999年 2 月 8 日採用決定］ 